\title{
What Makes An "Effective" Leader: The Application of Leadership
}

Charles E. Notar (Corresponding author)

College of Education and Professional Studies

700 Pelham Road North

Ramona Wood A3

Jacksonville State University

Jacksonville, Alabama 36265-1602

Tel : 1-256-782-5832Ｅ-mail:cnotar@jsu.edu

Carol S. Uline

Jacksonville State University

College of Education and Professional Studies

Department of Secondary Education

Jacksonville, Alabama 36265-1602

E-mail: culine@jsu.edu

Charlotte King Eady

Jacksonville State University

College of Education and Professional Studies

Department of Educational Resources

Jacksonville, Alabama 36265-1602

E-mail: ceady@jsu.edu

\section{Abstract}

This article is based on the premise that leadership is leadership, whatever the profession. A number of "leaders" from various enterprises are discussed to determine the basic tenets of leadership. The nine tenets of leadership are:

(1) Think and Act Strategically.

(2) Understand and Demonstrate the Elements of Teams and Teamwork.

(3) Master Small Group Decision Making.

(4) Clearly Define Roles and Relationships.

(5) Establish and Abide by a Leader-Subordinate Partnership.

(6) Implement Systematic Evaluation of Policy.

(7) Allocate Leader Time/Energy Appropriately.

(8) Set Clear Rules and Procedures for Meetings.

(9) Learn and Develop Continuously as a Leader.

Keywords: Leadership, Strategic Thinking, Teams and Teamwork, Small Group Decision Making, Role and Relationship Definition, Leader-Subordinate Partnership

\section{Introduction}

Tony Soprano, Vince Lombardi, George Patton, Jean Luc Picard, Rudolph Guiliani, Colin Powell, Marva Collins! You may wonder what any of these famous people have to do with leadership. They are regarded as being leaders. The authors of this article believe that leadership is leadership, whatever the profession. Regardless of scale or enterprise, there are tenets that are foundational to leadership. The literature about the individuals named previously uses various terms in its detailing how each is a leader. The authors have chosen the word tenets to embrace the terms used in the literature for leadership: traits, abilities, dispositions, characteristics, and principles. 
One answer to the question, "What makes a leader?" is this: Leaders have the qualities of determination, unselfishness, and motivation. They also possess the ability of having "people pay attention to them." Moreover, leaders inspire subordinates to achieve their potential and show them that the whole can be far greater than the sum of the parts. In addition, leaders possess good judgment, an uncanny ability to spot talent that fits the needs of the organization and situation. To that end, leaders seek people with character as well as courage and develop them into "on-field leaders," to use a football metaphor. A leader's organization must provide an atmosphere of mutual admiration, a suppression of egos, and a team concept to allow the leader to overcome adversity.

Ask people about their leaders or their organizations, and what would they say? Would they say "close knit," "unselfish," "proud," "well-coached," or "admired?" If so, how do the leaders make this happen? Leadership.

Thomas Cronin, (1992), a recognized authority on public policy, defines leadership as making things happen that might not otherwise happen, and preventing things from happening that ordinarily might happen. It is a process of getting people together to achieve common goals and aspirations. Leadership is a process that helps people transform intentions into positive actions, visions into reality.

\section{Think and act strategically}

In essence, the quality of leadership effectiveness is the result of disciplined adherence to a set of fundamental tenets and skills that characterize an individual. One such tenet is to think and act strategically. In fact, a leader's primary responsibility is not just developing policy; a leader must accept responsibility for shaping the future of the organization (or in an educational sense, a school or school system) by expanding mental horizons to identify and meet the challenges of the future. Marva Collins, after developing her Westside Preparatory School demonstrated this tenet by shaping the expectations for her students who were labeled "problem students" and learning disabled students. Dr. Collins sets policy: I think of how many times visitors from all over the world have come to Westside Preparatory School and remarked: 'It's amazing what you do here with children.' I then think how many times we have called the profits of a billion-dollar corporation 'a miracle.' We expect profits; we expect success. Why then can't we expect the same success from our children? (para. 3)

It is the policy of Westside Preparatory to expect nothing less than success for each student at the school.

An effective leader must have a strategic perspective always operating from the future and guiding others to the future. The leader starts with a vision and then defines the necessary strategic issues to achieve the vision. The next step is to develop long-range goals that address these strategic issues and provides decision-making and budgetary focus for the successful implementation of these goals. Living from one annual budget to another, and from one meeting to the next, condemns a system and its future to happenstance and condemns the leader to function only as a situational leader. This type of thinking confuses governance and policy. Subordinates expect leadership, sound thinking, and decisive action.

\section{Understand and demonstrate the elements of teams and teamwork.}

Another tenet of an effective leader who thinks and acts strategically is to understand and demonstrate the elements of teams and teamwork. By law, leaders exist and have authority only when their members convene as a "body" to do business. They also are a component of a corporate being which must speak, act, and fulfill its commitments with one voice, in a mature, effective, reliable manner. Consequently, leaders, a collection of diverse individuals, come together to constitute and act as an entity, and only when operating as this entity can they exercise authority and fulfill their purpose. This is a classic definition of team. Carl Larson and Frank LaFasto, (1989) two authorities on teams and teamwork, define "team" as an entity comprised of two or more people working together to accomplish a specific purpose that can be attained only through a coordinated activity among the team members. In short, a team exists to fulfill a specific function or purpose and is made up of disparate, interdependent parts (individuals) who collectively achieve a capacity that none of its members could achieve individually.

Leaders are the catalysts for actualization. They ferment the mix. They create synergy. The word synergy sounds like energy. Synergy results from rallied energy. Leaders ignite a spark that causes the group to achieve an output together that could not be achieved through individual efforts.

While many team efforts are productive, few are synergistic. To create synergy, leaders inspire commitment to team success and quality performance. Leaders focus the energy of individuals and allow them to accept responsibility for the group product. Leaders light the fire of desire which flames into action and produces an explosive burst of accomplishments. Success feeds success as individual interests are redirected into group goals. Hence, a culture of synergy emerges that enables empowered people to produce well beyond the most optimistic predictions.

Members of a team can not be synergistic unless they understand, master, and demonstrate the fundamentals of teamwork:

(1) A clear sense of purpose and goals;

(2) A team performance based on clearly defined roles and relationships that unite individual talents and capacities; 
(3) An integration of members who have basic technical, interpersonal, and rational decision-making competency;

(4) A commitment to team success and quality performance;

(5) A climate of trust, openness, integrity, consistency, and mutual respect;

(6) A set of clear standards outlining success and performance excellence;

(7) The support, resources, and recognition to achieve success; and a principled and disciplined leadership.

\section{Master small group decision making}

A third tenet of leaders is the time they spend building their sense of team and developing the skills for productive teamwork. To build a team, a leader must have the ability to master small group decision making. Most staffs are classic small groups of fewer than a dozen people. They demonstrate certain skills and behaviors that "link" their members together, as well as the processes they follow to make decisions to fulfill their group's purpose.

People are motivated by external rewards, such as bonuses, benefits, promotions, incentives, and pay raises. Internal rewards are even stronger motivators. Everyone wants to feel important. People crave self-respect and the respect of others. They work for the approval of their peers as well as their leaders. People respond to well-deserved praise. Rewards for individual talent, achievements, and accomplishments, come in the form of certificates, letters of appreciation, positive notes, or a simple "Thank You." Workers need to hear that their efforts made someone else's life a little easier. These gestures of gratitude are powerful motivators that affect the mental, emotional, and spiritual state of a person. When employees perceive that they are appreciated and valued, trusted and treasured (Stuart \& Crom, 1993), they take pride in their role as part of the team and share ownership in its accomplishments. When the workers' psychological needs and personal values are satisfied, productivity and profitability of the organization increase proportionally. Organizational performance thrives on personal achievement.

\section{Clearly define roles and relationships}

In any organization, leaders must be able to clearly define roles and relationships, another characteristic of effective leadership. Tony Soprano, in one of the episodes of the Sopranos, told one of his lieutenants after he had done something inappropriate "You're a capo, act like one." Each team member's contribution to the team relationship (i.e., school board member, superintendent, staff, principal, teacher, parent and student, etc.) must be defined in terms of roles to be assumed (function) and how those roles are to be carried out through behavior (performance). A role has two elements: function or what the specific responsibilities of that role are irrespective of incumbency and performance; and, how the person occupying the role is expected to behave and to fulfill his responsibilities. Leaders must have a clear definition of function. The performance component must be defined within the team through discussion and mutual definition of behaviors and practices expected of the leader and subordinates.

Lee Iacocca when discussing teamwork in his biography uses a legend of the National Football League. Vince Lombardi,when asked, "What makes a winning team?" replied,Start with the fundamentals. A player's got to know the basics of the game and how to play his position. The players have to play as a team, not as a bunch of individuals. The difference between mediocrity and greatness is the feeling the players have for each other.

The team concept facilitates expected roles and relationships and gives constructive feedback to its members as to the degree to that they are fulfilling these expectations.

\section{Establish and abide by a leader-subordinate partnership.}

Subsequently, these tenets lead to the tenet establish and abide by a leader-subordinate partnership. Subordinate means staff, followers, employees, participants, those individuals who work with a leader. The statement "Leaders make policy; subordinates implement policy" is a misconception of reality. Policy-making and policy-implementation are not distinct, separate functions. Policy-making/implementation is a continuum of thought and relations that transform ideas and abstractions (visions, policies, goals, plans, etc.) into defined observable ends or outcomes (results, programs, buildings, streets, deliverable services, etc.). Leaders and subordinates share this continuum as partners, ensuring each other's success. Each person plays an important role in creating sound policies and ensuring their effective implementation through reliable administrative practices and performance. John Carver, (1990) a widely acclaimed author who writes about staffs that make a difference, discusses this partnership as one in which leaders define what needs are to be met and what ends (outcomes) are to be achieved. Carver believes that leaders should allow staff (within a leader's established limits) to define the means for achieving these ends and to establish a leader-staff linkage that empowers staff to do its tasks and to be evaluated on the results produced.

Leaders who accept and abide by this partnership focus on vision and goals, good policy, and effective staff performance. Those who do not engage in leader-staff partnership fall prey to micromanaging - a perceived need to become involved in, or retain approval over, staff activity and plans. 


\section{Implement systematic evaluation of policy}

The leader-staff partnership is based on the ability to implement systematic evaluation of policy, another effective leadership characteristic. Leaders frequently fall into the "Jean-Luc Picard" syndrome (Star Trek II): "Make it so." They assume that a leader's action equates to policy/program implementation. The next time leaders hear about the policy is when a problem or a crisis arises. However, effective leaders expect periodic feedback on policy results and possible policy amendments as required. This feedback can be provided through progress reports, in-process reviews, policy reviews, and after-action reviews.

\section{Allocate leader time/energy appropriately}

In reality, a leader knows he/she cannot be everywhere at the same time. To be at the right place at the right time, a leader must be able to allocate leader time/energy appropriately, the seventh characteristic of effective leaders. Leaders "play" in a number of settings or 'arenas" to achieve overall, peak performance. The following four arenas have their own purposes and contributions to a mission's effectiveness:

(1) Goal-setting (retreats or meetings).

(2) Exploration and analysis (study sessions).

(3) Disposition/formulation (regular group meetings).

(4) Community (interactions with families and other agencies).

Effective leaders have at least one goal setting retreat or meeting annually. They also must have two staff meetings monthly, usually in the weeks between regularly-scheduled higher level staff meetings. Here, they confer with their staffs and other experts about significant items under consideration requiring eventual actions. Unfortunately, many leaders short-change this arena, pushing the opportunity for learning into the formal staff meetings which are not designed for, nor capable of, promoting much in-depth analysis of complex issues. Actually, the disposition/formulation arena is designed to get to a vote, not to promote careful analysis of complex issues.

However, the community arena is becoming more important because it is rapidly transforming the role of leader and how a leader's time is spent. Communities today are more dependent upon sophisticated alliances and partnerships among groups, public and private entities, and multiple government agencies to negotiate complex and multi-jurisdictional (regional) issues. The most profound change in how leaders operate is occurring within this arena which requires more time in interactions outside of the unit and puts more time constraints on subordinates and staff.

\section{Set clear rules and procedures for meetings}

For a leader to use time and energy wisely, he/she must be able to set clear rules and procedures for meetings, the eighth tenet of effective leadership. Meetings exist for the purpose of doing a leader's business. Literature on how to conduct effective/productive meetings details the need for and adherence to clearly defined rules and procedures. Many leaders, however, drift from these rules and procedures in pursuit of informality, collegiality, and "just being nice." They let their meetings drone on with lack of focus, redundant comments, and endless discussions. Rules and procedures do not preclude staff input, courtesy, or sensitivity to everyone's concerns and viewpoints. They respect all these elements in addition to the necessity to conduct business in an orderly, disciplined, productive manner.

\section{Learn and develop continuously as a leader}

The last tenet of a leader is to learn and develop continuously as a leader. Leadership growth flourishes with self study, education, training, and experience. As a leader grows, so does the performance of everyone within the organization. According to Peter Drucker (1993), when discussing developing executive effectiveness, states it requires changing people's preoccupation with problems to a vision of opportunity, from concern with weakness to exploitation of strengths. Rudy Giuliani (2002) has a chapter in his book Leadership entitled: "Study. Read. Learn Independently."

Leaders must decide what their role is, identify the skills needed to be effective in that role, and then GET TRAINED! Highly effective leaders honestly know they don't know everything; therefore, they take advantage of the myriad of opportunities to learn and perfect their skills by reading and attending courses, conferences, workshops and every forum in order to expand their skills to lead and govern well.

Highly effective leaders also learn as leaders. They objectively assess their performance of each of the nine tenets. They decide where gains can be made, then set up the opportunity through workshops to learn the skills to make these gains.

\section{Conclusion}

The last and probably most important point is this: Effective leaders keep a sense of humor. Leading is serious business for those of us in education. As we deal with vital issues affecting the lives of our students, our teachers, and our systems, and the quality of life we experience daily within them, we must keep a sense of humor. Humor reduces friction and stress, lets others know we and they are human, and is a pause that refreshes our insight and commitment. It is essential to creating and maintaining relationships. 
Every school board, superintendent, principal, teacher, parent and student deserves nothing less than highly effective leaders who embrace and accept accountability for their performance in creating its future, and effectively addressing, in the present, those issues and challenges vital to attaining that future. That is what is at stake-our country's future. With few exceptions, every leader can be highly effective and can provide strong leadership, but to do so requires a disciplined adherence to the fundamental tenets of effectiveness. Our training programs for educational leaders must address the nine tenets.

\section{References}

Batory, J. P. (2004). Philosophy for leadership. School Administrator, 61(2), 51.

Bell, T. H. (1994). Educational leadership in the 1990s. School \& College, 33(1), 9.

Bennis, W. (1999). Five competencies of new leaders. Executive Excellence, 16(7), 4-5.

Conn, J. (1995). 10 traits of an effective leader. Florist, 29 (1), 30-33.

Carver, J. (Mar 2000). Remaking governance. American School Board Journal, 187(3), 26-30.

Carver, J. (1990). Boards that make a difference: A new design for leadership in nonprofit and public organizations. San Francisco, CA: Jossey-Bass, Inc.

Collins, M. (1995). Why I teach. Black Collegian, 25(2). Retrived from EBSCO host databases.

Cronin, T. E. (1992). Thinking and learning about leadership. Military leadership: In pursuit of excellence. Taylor, R. L. \& Rosenbach, W. E. (Eds.) Boulder, CO: Westview Press.

Davies, B. (2002). Rethinking schools and school leadership for the twenty-first century: Changes and challenges. International Journal of Educational Management, 16 (4), 196-206.

Davis, P., Naughton, J. \& Rothwell, W. (2004). New roles and new competencies for the professional. $T+D$, 58(4), 26-36.

Davis, S. H. (1998). Taking aim at effective leadership. Thrust for Educational Leadership, 28(2), 6-11.

Drucker, P. F. (1993). The Effective Executive. New York: Harper Business, Division of Harper Collins Publishers, Inc.

Duemer, L. S., Christopher, M., Hardin, F., Olibas, L., Rodgers, T. \& Spiller, K. (2004). Study of characteristics of effective leadership in graduate student collaborative work. Education, 124(4), 721-726.

Gabriel, G. G. (2005). How to thrive as a teacher leader. Alexandria, VA: ASCD.

Giuliani, R., \& Kurson, K. (2002). Leadership. New York, New York: Miramax Books.

Hanft, A. (2004). What I learned from the Sopranos, Inc. 26(5), 130.

Harari, O. (2002). The leadership secrets of Colin Powell. Boston: McGraw-Hill.

Harkin, W. J. (2002). The stuff of leadership. Marine Corps Gazette, 86 (9), 88-89.

Horan, J. (1999). Leadership. Orana, 35 (2), 19-25.

Iacocca, L. (1999). Teamwork. www.solutiond.com/perf-lombardi-on-teamwork.htm.

Julian, L. S. (2002). Four traits of a successful leader. Nation's Cities Weekly, 25(34), 10.

Larson, C. \& LaFasto, M. J. (1989). Teamwork: What must go right/what can go wrong. Newbury Park, CA: Sage Publications

Lauer, C. S. (2002). The basic recipe for a leader. Modern Healthcare, 32(8), 33.

Levine, S. R. \& Crom, M. A. (1993). The Leader in You: How to win friends, influence people, and succeed in a changing world. Dale Carnegie \& Associates, Inc. New York: Simon \& Schuster.

Little, L. (2004). Kolb's learning styles for leaders. Administrator, 23 (8), 8.

Mariotti, J. (1999). The role of a leader. Industry Week/IW, 248 (3), 75.

Noonan, S. J. (2003). Elements of leadership: What you should know. Lanham, Md.: Scarecrow Press.

Pollock, T. (2002). Things a good leader does. Electric Light \& Power, 80 (11), 37, 43.

Professional Development Collection. (2002). Born leaders? Training, 39 (9), 22.

Stanley, T. L. (2001). Is there a leader in the house? Supervision, 62 (6), 9-12.

Weiss, W. H. (2004). Effective leadership: What are the requisites? Supervision, 65(1), 14-17.

Zimmerman, E. L. (2001). What's under the hood? The mechanics of leadership versus management. Supervision, 62 (8), 10-12. 